\title{
On the Innovative Construction of the Cohesion of the Grassroots Party Work Team in Colleges and Universities from the Perspective of Psychology
}

Jin Fan

\author{
Wuhan University of Technology, Wuhan, P.R.China, 430070
}

\author{
(E-mail: 1060887801@qq.com)
}

\begin{abstract}
With the development of modern education, higher education becomes more and more prominent in modern education. Grassroots Party work team in colleges and universities as an important part of the construction of the grassroots Party organization, its influence should not be overlooked. But at present, there exist many problems of the thinking and understanding on the construction of the grassroots Party organization, which hinder the healthy development of the new Party work period. Therefore, solving the problems of Party organization construction from the perspective of psychology quickly and effectively, and establishing a cohesive grassroots Party work team has become an urgent need of the present era. This paper introduces the basic concept of cohesion, analyzes the significance of the cohesion construction of the grassroots Party work team in Colleges and Universities under the background of psychology, introduces the current situation of the grassroots Party organization cohesion construction, and put forward problems and some effective suggestions and countermeasures of the innovation construction of the cohesion of grassroots Party work team from the perspective of psychology, which is of referential significance.
\end{abstract}

Key words: psychology; grassroots in colleges and universities; Party work team; cohesion

\section{Introduction}

The university is to cultivate youth, and grassroots Party work is an important aspect of College grassroots organizations, in which team cohesion is very important. A team full of cohesion is very important, which reflects the overall quality and comprehensive ability of the grass-roots Party organization, which represents image of the Communist Party. It can play the exemplary role of Party members, and is the driving force of the effective work of the grassroots Party work team, being of far-reaching significance to the youth.

\section{Analysis of the outer and inner cohesion of the grassroots Party organization in colleges and universities}

\subsection{Inner Cohesion}

The inner cohesion of the grassroots Party organization refers to the cohesion of emotional resonance and behavior consistency of all the Party members, including comprehensive quality and ability of the whole team synthesized by each member, the sense of honor and sense of mission, working enthusiasm, conscientious and responsible working attitude and so on. The grass-roots Party organization cohesion is the core of the construction of the grassroots Party organizations, which directly affects the Party work, should not be ignored.

\subsection{Outer Cohesion}

From the external environment influence force is called outer cohesion. With adequate capital and funding for training and specific business communication, increasing the opportunity for members to learn from each other, helps to improve the outer cohesion. In addition, outer cohesion also includes attraction and charm of Communist Party of China (short as CPC), as well as CPC can meet physical and psychological needs of members, which means the members have a sense of belonging to $\mathrm{CPC}$.

\section{The significance of the cohesion construction of the grass roots Party organizations in colleges and universities under the background of Psychology}

\subsection{The cohesion is not enough}

The establishment of a cohesive university grassroots Party work team is a necessary condition to promote the construction of the grassroots Party organization. If the grass-roots Party organizations lack of cohesion, the members cannot work full of passion, which to a certain extent 
weakened the Party organization's service function, and the Party work cannot effectively complete on time, leading to the grassroots Party organizations cannot establish the authority. Uneven quality, low comprehensive quality and ability, lacking of sense of mission and honor mean the grassroots Party organizations lack of cohesion. Therefore, in order to promote the development of the construction of the grassroots Party organization, it is imperative to strengthen the construction of team cohesion.

\subsection{Focusing on the cultivation of socialist builders and successors}

The university is a holy land of national selection and train of youth. Strengthening the construction of grassroots Party organizations, and establishing a cohesive team are responsible for the country and the nation. It meets people's expectations of obtaining actual effect. It has a very profound impact on improving the comprehensive quality of members, cultivating a new generation with lofty ideals, moral integrity, good education and a strong sense of discipline, and cultivating a new generation of socialist builders and successors who contribute to the country, for the talents reservation, for the country's economy and security development.

\subsection{Cohesion can resist all kinds of challenges}

The establishment of the grassroots Party organization team with strict organizational discipline, consummate business ability, spirit of innovation and strong political ideas is a guarantee of cultivating excellent talents for nation. The members of the organization with high comprehensive quality and ability can face difficulties and challenge bravely, is an important guarantee for national security.

\section{The construction of grassroots Party organizations}

Adhere to the Marxism-Leninism, Mao Zedong Thought, Deng Xiaoping Theory and Thought of Three Represents as the guide, comprehensively implement Scientific Outlook on Development, and form a grassroots Party work mechanism with clear responsibility, strong leadership, orderly operation and security in place. Promote scientific, institutionalized and standardized grassroots Party work, and provide a strong organizational guarantee for the reform and development of the school.

The grassroots Party workers belonging to the Party committee. Under the leadership of CPC, the grassroots Party workers directly contact with the public people, and is responsible for the Party construction in colleges and universities. The school principals, The Party committee secretary and Deputy Secretary of the Party committee are the first responsible persons of the grassroots Party work, and leading cadres of Party members in charge of their own parts. The Party committee should regularly listen to the Party branches' work report, discuss and research problems such as work style construction, thought and organization, to form the unified leadership of Party committees, concerted mechanism. The grass-roots Party branch secretaries are first responsible persons of the Party development work in colleges and universities. They are primary responsible for guiding the Party construction work in their own branches. They shall earnestly research and organize work plan and opinions in stages, carry out and supervise specific tasks.

The work of Party development includes two aspects, the theory and practice construction, which can be divided into organization construction, ideological construction, system construction, style construction, discipline construction and so on, and the Party's organization construction includes system construction, team development and position construction.

\section{Implications of psychological cohesion theory}

Cohesion refers to the attraction which an organization attracts members with good vision or lofty goal; members of the organization have mutual attraction and unity because of sense of identity based on the same target, values and ideality. In psychology, we think organization's attractiveness and members' inner cohesion form the organization's cohesion, which are impacted by the external and internal factors. The internal factors are from team members, and the external factors are from environment. The formation of organizational cohesion can be divided into three stages: the attracting goal, members gathering; power influence, demand are met; emotion strengthening, voluntarily attributing.

The attractiveness of an organization are mainly as follows: first, organizational attractiveness. If the organization has the form of organization, social position, charm of person in charge, good vision and clear direction and other conditions, can it attract members to join the 
organization, the form cohesion; instead the organization does not have these factors will not be able to appeal to members, and even members may separate themselves from the organization. Second, organization can meet the needs of members. The organization using its power fights for money or welfare for members, to meet members' physical and psychological needs, then makes members voluntarily obey, and have the sense of belonging and responsibility. The cohesion between members of the organization refers to the members have the same sense of belonging, they can unit and cooperate with each other. When members of the organization work hard for the common interests, united and harmonious, love each other, its attraction will be large. On the contrary, the smaller the attractiveness will be, even may cause resentment, mutual exclusion.

\section{Conclusion}

The development of colleges and universities cannot do without the work of grassroots Party organizations. The Party work teams is an important part of the grassroots party organization. Ensuring its cohesion is the trend of the times and cannot be changed. The Party cadres and grassroots party workers have made outstanding contributions to the construction of basic party organization which cannot be wiped out. But we also need to find the problems and find ways to solve them. College students' employment and development mainly depend on cultivation in colleges and universities. Grassroots party staff should keep their firm ideals and beliefs, devote themselves to the Party organization work, improve their comprehensive quality, and develop a grassroots Party work team full of cohesion, to promote the work of grassroots Party organizations and development of colleges and universities.

\section{References}

[1] Huang Shiqiang, On the Innovation of the Construction of the Cohesion of the Grassroots Party Work Team in Colleges and Universities from the Perspective of Psychology[J]. Science Consult, 2013, (34).

[2] Wu Ruilin, Wang Jianzhong, The Cultivation of Innovative Talents in Colleges and Universities from the Perspective of Psychology[J]. Theoretical Front in Higher Education,2012, (7).

[3] Hu Peil, On the Innovation of the Training and Education of the Party Stuff in Colleges and Universities in the New Era[J]. Entrepreneur World,2014, (2).

4] Du Songqi, Innovation of the Grassroots Party Construction under the Guidance of Scientific Outlook on Development----Investigation and Reflection on the Grassroots Party Work in Colleges and Universities[J]. Journal of Tianshui Normal University,2009,29(3).

[5] Chen Feng, On the Present Situation and Countermeasures of the Party Work Team Construction in Colleges and Universities in the New Era[J]. Journal of Qinzhou Teachers College,2005,20(4).

[6] Ma Ying, Strengthening the Party Work Team Construction and Speeding up the Scientific Development in Colleges and Universities[J]. New Curriculum Research: Higher Education,2012, (1).

[7] Huang Xiaoli, The History and Present Situation of the CPC's Ideological Construction in University[D]. Fujian Normal University,2005.

[8] Zhu Huiqiong, On Improving Party Workers' Comprehensive Quality under the New Situation[J]. Journal of Anhui University of Technology (Social Sciences Edition), 2008,25(4). 